\title{
15 THE PRESENCE OF THE PAST Imagination and Affect in the Museu do Oriente, Portugal
}

\section{Elsa Peralta}

In 1983 UNESCO designated the Monastery of the Hieronymites and the Tower of Belém in Lisbon as World Heritage Sites. According to UNESCO's website, the monastery "exemplifies Portuguese art at its best" and the Tower of Belém "is a reminder of the great maritime discoveries that laid the foundations of the modern world." ${ }^{1}$ Less than 10 years after the formal end of the Portuguese colonial empire, UNESCO made use of the exemplar of Portuguese art to reaffirm the long-used interpretive framework through which Portuguese imperial history has been read both nationally and internationally: Portugal was the country of the "Discoveries," not a colonial center. Widely disseminated through schools, public discourses, and propaganda since the end of the nineteenth century, this interpretation of Portugal's imperial history is strongly embedded in the country's material culture. The naming of streets, bridges, schools, theaters, and monuments after "heroes," sites, or themes of the Discoveries operates to establish a forceful intimacy with the past, which is materially embedded in the very experience of the space itself. In addition, the public displays, exhibitions, and museums that address the topic - with objects that are often treated as art or antiques unfailingly exalt the material and visual properties of the objects that testify to Portugal's imperial deeds. I argue that this focus on materiality, together with an aesthetic lauding of historical objects, has contributed greatly to the resilience of the established view of Portugal's imperial and colonial past, and made it resistant to modes of representation other than the nostalgic mode of historical grandeur and civilizing legacy. In this chapter, I will look at the Museu do Oriente (Museum of the Orient), in Lisbon, Portugal, and more specifically at one of its permanent exhibitions, The Portuguese Presence in Asia, in order to understand how objects, 
together with communicative media, generate affects and draw the imagination toward Portugal's past and its empire.

\section{Museums and affect}

Museums and their objects are common ways by which nations are performed and materialized. Museums encode and convey meanings about nations and their pasts, through which one can read the nation and learn about its history. Moreover, the meanings conveyed by museums and exhibitions generate an effect: they lead people to subscribe to a certain view of history; they provide a coherent narrative for a community thus imagined in relation to an often mythical past; and they give a moral impetus to a collective path. However, the question too often disregarded is how they do this, as Sandra Dudley $(2010,3)$ rightly points out. If museums perform national pasts, and motivate people to subscribe to the meanings they want to convey, museums must somehow affect those who visit them. But the question remains as to how that productive affect is manifested and incorporated into and through the practices of museums. Is it the contextual information that accompanies the objects and the interpretive framework provided by exhibitions that affects their viewers? Are the objects displayed in specific exhibitions speaking to emotionally charged subjectivities and thus rendered affective? Or is it the objects themselves that discharge those affects? (Navaro-Yashin 2009).

The growing attention paid to objects after the "material turn" in the social sciences is at the root of these questions. The emphasis on meaning established by the dominant structuralist and poststructuralist analysis of language and discourse has been increasingly reconsidered by an "examination of the physical actuality of objects and the sensory modalities through which we experience them" (Dudley 2010, 2). As Andrea Witcomb claims, "objects need to be understood to embody, rather than articulate, meaning" $(2010,41)$. In addition, the influence of the work of Alfred Gell (1998) in the field of the anthropology of art has contributed a great deal to the growing attention to the object itself - in this case, an art object - as a physical entity that mediates and creates social relations. And, finally, the "affective turn" has come to demonstrate that affectivity can be studied in sites beyond the scope of the interiority of the human subject. Following Deleuze's postsubjective theory of affect, many things other than "human subjects," such as bodies, objects, space, and the environment, can be understood as possessing affective powers as well. Affect here should not be confused with sentiments, emotions, and feelings. As Brian Massumi makes clear in his introduction to Deleuze and Guattari's $A$ Thousand Plateaus, affect "is an ability to affect and be affected" (1987, xvi). Affect is a response to a stimulus, a "sensual intensity," which may move through the subject, but does not necessarily emerge from it (Navaro-Yashin 2009, 12).

This does not mean ascribing fixity or complete autonomy to the affective domain. As a matter of fact, the affective power of things and bodies in the world 
is pretty much intertwined with subjective feelings and emotions. On the one hand, the affects produced differ according to their recipients and to their psychological dispositions. On the other hand, those psychological dispositions that make people respond differently to the same affect are also socially constructed and are thus dependent on class, gender, and politics. And it should be added that people can resist the structure of the affective experience that is being delivered to them. As such, although I am interested in an object-oriented approach (Latour 2005; Henare, Holbraad, and Wastell 2007), I would add to the horizontal network of assemblages of affecting "things" (people and objects) the historical contingencies and the political specificities that also determine those relationships (NavaroYashin 2009, 9). Context - social and political - is a vital element in the constitution of affect. In addition, following Nigel Thrift's spatial theory of affect, we should not forget that "affect has always been a key element of politics and the subject of numerous powerful political technologies" (2004, 64), calling to mind the manifold ways by which affective responses are designed into spaces. Affects can thus be manipulated in accordance with political agendas and practical knowledges. In this sense, issues of identity and belonging cannot really be addressed if affect is not taken into consideration.

This approach has slowly come to influence contemporary museum studies. Dipesh Chakrabarty called attention to the domain of "the embodied and the lived" $(2002,9)$ in today's museums, arguing that exhibitions provide as much experiential as abstract knowledge. Drawing on the work of Chakrabarty, Gregory and Witcomb $(2007,263)$ have argued that the museum experience must be understood through a consideration of the visitors' use of the senses, rather than their analytical processes. Sandra Dudley, in her edited volume Museum Materialities, sets out to explore the "subjective experience - physical, multisensory, aesthetic, emotional, immersive - of publicly displayed objects" (2010, 2), while Nayanika Mookherjee (2011) argues that we need to identify how museums structure their exhibitions to generate affective responses to regulate sentiments of belonging to the nation and its past. This chapter tries to draw on these influences in order to understand how the Portuguese national past is imagined and affected in the museum space through the presence of objects.

\section{Portuguese national identity and the empire}

Portuguese national identity is strongly focused around the empire and the historical experience of Portugal as an imperial power. The Portuguese Empire, which began in the fifteenth and sixteenth centuries with the search for a sea route to India and the establishment of a commercial domain in the East, lasted for more than five centuries. When the domain in the East grew weaker with the arrival of competing European powers, the center of the empire moved to Brazil and, when Brazil became independent in 1822, it shifted to Africa, until several years of 
colonial wars and the fall of the dictatorship in Portugal in 1974 paved the way for decolonization. It is the period known as the "Eastern Empire" that came to be constantly reproduced in various arenas of public culture and retained in the collective imagination as the golden age of Portuguese history. Since the end of the nineteenth century, a gradually built discourse, embodied in official practices and portrayed in the nation's cultural life, has firmly instilled a national imperialism into the representation of its history. Accordingly, a host of national symbols were created on the basis of an imperialist self-definition of the country's national identity. Luís Vaz de Camões, author of the epic poem The Lusiads, published in 1571, became one of the greatest national heroes, and his voice continues to mediate how we understand this empire. His importance is clearly articulated by the decision to designate June 10, the day of his death, as the Day of Portugal. A new national anthem, whose tone is national imperialist, was written, and a new national flag designed, with the armillary sphere of the navigators at its center to convey Portugal's self-representation as a country of Discoveries rather than as a colonizing center (Peralta 2011).

Since then, the "Orient" has populated the Portuguese collective imagination with chimeras, adventures, and glory, even if all that was left of the Eastern Empire was eventually reduced to a few small possessions which Portugal maintained through diplomatic efforts. These would serve in several instances as a "reminder" of the "historical right" of Portugal to possess colonial territories. During the Estado Novo (New State) dictatorship, when the legitimacy of Portuguese colonial rule was being called into question, an imperial mystical discourse was meticulously constructed (Bethencourt and Chaudhuri 1999, 24-30). A national imperialist pedagogy was devised which was firmly entrenched in the educational curriculum. It emphasized the cult of national heroes and the idea of the historical mission of the Portuguese nation, a mission marked by Christian ideals and the colonial vocation.

This theme - which was also disseminated through publications, popular culture, and cinema, as well as fairs and exhibitions both in Portugal and abroad grew out of the idea of the missionary vocation of Portuguese expansion in the world. It created an image of a moral empire that would be essentially different from other European empires, which were taken to be purely instrumental or secular in nature. In a speech delivered on May 28, 1936, Salazar proclaimed: "Missionary vocation one has been able to call it - this universal, deeply humane tendency of the Portuguese people, due to their spirituality and disinterestedness" (quoted in Bethencourt and Chaudhuri 1999, 32). In a context marked by disputes over imperial hegemony, Portuguese imperialism was thus justified on moral grounds, and by the "spirit" that dates back to the first voyages of the Portuguese navigators. Portuguese imperial discourses are, thus, based on an emotional rationale which stresses the intimate affective relationship with the empire, "Portugal's home, body and soul," in the words of Armindo Monteiro, a 
minister of colonies in the Estado Novo (quoted in Bethencourt and Chaudhuri 1999, 24). This emotional rationale is also the basis of the conception of Portuguese colonialism as nonracist, encouraging "miscegenation" and cultural equality between the colonizer and the colonized. When, after World War II, Portugal's colonial regime was increasingly challenged by the colonies' aspirations to self-determination, the term "Lusotropicalism" was coined by Gilberto Freyre, a Brazilian sociologist who sought to highlight the benevolent nature of Portuguese colonialism in several of his works, to refer to late Portuguese colonialism in the Tropics.

The notion that Portuguese colonialism was humanistic and nonracist is still deeply ingrained in the imaginary of the Portuguese people today. The fall of the Estado Novo regime in 1974, and the process of decolonization of the Portuguese colonies in Africa that followed, were accompanied by little critical discussion in the public arena of the issues surrounding empire and colonialism. Poetry, literature, and politics continue to repeat the ideology of Lusotropicalism, and expressions of public culture, including museums, have continued to mediate the historical experience of the empire through the history of the Discoveries, which is primarily perceived as a time of glory, adventure, and the meeting of different peoples. This reading provides a very positive framework for the Portuguese colonial experience which mitigates its nefarious effects compared with other colonial systems. It also projects an image of Portugal as a European pioneer, claiming for the country a high-ranking position in the new European space where Portugal is now placed. As Power and Sidaway remark, "In this spirit, Portugal has positioned itself as the exemplary European nation, insofar as it was the supposed pioneer of exploration; the site of departure" (2005, 879).

\section{The Museu do Oriente}

It is difficult to distinguish the Museu do Oriente building from the other buildings in the port landscape where it is located, except that it has been renovated and is gleaming. It used to be an enormous warehouse where cod and other food supplies were stored and preserved. Named after the Portuguese navigator who reached Brazil in 1500 - Pedro Álvares Cabral - the building was designed by João Simões Antunes who imposed his modernist style on the whole design, according to the rationalist trend and the popular iconography that characterized Estado Novo architecture. The building has a longitudinal and symmetrical white marble structure, with a dominant central body flanked by two lower wings. On the facade of one are bas-reliefs illustrating cod fisheries and the storage of fresh fruit; on the other is the state coat of arms with the date 1940, the year of the Exposição do Mundo Português (Exposition of the Portuguese world), the most complete example of Estado Novo national imperialist propaganda. 
The building functioned as a warehouse until 1992, when it was closed down. By then, the Fundação Oriente (Orient Foundation) was already established. The Foundation was set up in 1988 by the Sociedade de Turismo e Jogo de Macau (Tourism and Games Society of Macau) as required by the Portuguese administration of Macau in exchange for the exclusive rights to operate the gambling business in the colony. The history of the foundation is closely connected with the history of Macau. More specifically, it is related to the preparation for the handover of Macau to Chinese sovereignty in 1999, after centuries of Portuguese administration. Macau became the first and the last European colonial territory in China. The Fundação Oriente came into being with the purpose of publicly acknowledging and continuing the historical and cultural relations between Portugal and China and between Portugal and other East Asian countries. Accordingly, the Fundação Oriente pursues, as set out in its bylaws, "activities of a cultural, educational, artistic, scientific, social and philanthropic nature ... that shall aim to develop and continue the historical and cultural ties linking Portugal and the Orient, specifically China." ${ }^{2}$

In pursuit of these activities, the foundation first opened offices in Macau and Lisbon (1991), then in Goa, India (1995), and finally in East Timor (2002), all of which were formerly part of the Portuguese Eastern Empire. From the outset, the foundation set the purpose of creating a museum that would testify to the relations between the Portuguese and East Asian peoples since the sixteenth century. According to Kam-yee Law (2013), in a paper on the constitution of museums in Hong Kong and Macau after their transference to China, the Portuguese strategy was to preserve their cultural heritage in and future influence on Macau after 1999. These aims were based on a series of claims for continuity, made on the basis of several long-used arguments which revolve around definitions of national identity, namely: Portugal as the "discoverer" of an empire without colonies and Portugal as a European pioneer which opened up the world to contact and cultural exchange. The "world" thus "discovered" by the Portuguese was designated as the Oriente (Orient), reflecting an emotive appropriation of the historical past. Thus, although it is a private foundation, the Fundação Oriente nonetheless plays a significant role in the definition of Portuguese nationhood. As the museum catalogue states: "As is universally known, Portugal was the first European country to reach the Orient by the Atlantic and the last to leave as an administering power of territories. The completion of the Museu do Oriente ... emerges as a national imperative" (Museu do Oriente 2008, 19).

The museum opened to the public in 2008. Prior to that, a collection was formed on the basis of two main ideas: that these objects were "works of art and collectors' items" and that they were "objects that tell the history of the Portuguese presence in Asia" (Museu do Oriente 2008, 10). This is unquestionably a museum conceived, first and foremost, as an art museum aimed at mediating historical understandings through the aesthetic qualities of historical artifacts. This was 
made clear in the words of the president of the Republic of Portugal, Aníbal Cavaco Silva, when the museum was inaugurated in 2008:

Here is assembled a remarkable collection of art pieces that testify what was the first experience of globalization proudly carried out by the Portuguese. ... We are now witnessing a new wave coming from the Orient. India and China take its place in the international context and it is impossible to ignore the relevance that they have today. This cultural space now opened will certainly be the scene of many initiatives that will allow us to better understand our Asian partners. (Presidência da República Portuguesa, n.d.)

The bridges established by cultural diplomacy thus rest on a marked aestheticization of the past, along with a very positive depiction of Portugal's imperial experience. Two main collections were, therefore, brought together which came to constitute the two permanent exhibitions of the museum. One of these is the Kwok On collection and exhibition, from the Association du Musée Kwok On, Paris, which consists of more than 13,000 objects from Asian performance arts related to religious practices. The other collection and permanent exhibition is The Portuguese Presence in Asia. Consisting of around a thousand objects acquired from national and international art markets, and from public and private collections, it mostly represents the geographical areas of China, Japan, East Timor, and India. In addition to housing these two permanent collections, the museum hosts a wide range of activities, from temporary exhibitions to workshops and concerts. While this multidiscursive approach adds plurality and contemporaneity to the historical and traditional approach of the two permanent exhibitions, the museum nonetheless presents past and present Asian cultures as part of a static and nonproblematizing Orient. Outside the museum, there is no trace of cultural activity. The area around the museum site is marked by port activity and there are restaurants, bars, and nightclubs. The museum is not widely visited and attracts a mostly specialized audience interested in the topics covered by the conferences, workshops, or shows held inside. Tourists sometimes include it in their itinerary on visiting Lisbon, and cruise ships docked nearby incorporate it into their program. It is against this backdrop that I shall analyze the exhibition The Portuguese Presence in Asia.

\section{The Portuguese Presence in Asia}

According to its curators, the main idea underlying the exhibition The Portuguese Presence in Asia was "the building of a Utopia of the Orient by the Portuguese from the fifteenth century to the present day, based on trade, missionary activity and the meeting of cultures" (Museu do Oriente 2008, 25). The word "utopia," coined from the Greek by Sir Thomas More for his 1516 book Utopia, has come to mean an imaginary or ideal country, or a place of ideal perfection. This reading of the 
Portuguese imperial undertaking as characterized by utopian ideals is a sublimation to which poetry and literature have contributed, in particular the works of Luís Vaz de Camões and Fernando Pessoa, who have been called the "poets of Utopia" (Prado Coelho 1983). The Lusiads, by Camões, is the Portuguese book par excellence. It narrates the fabulous voyage of the navigator Vasco da Gama in his endeavor to find a maritime route around the coastline of Africa to India, where he arrived in 1498. The narrative provides a fantastic and nostalgic view of the golden era in the nation's past, in which the Orient is a place of ideal perfection, a utopia. The Portuguese Presence in Asia pays full tribute to the poet and his poetry: it displays a facsimile copy of the first edition of The Lusiads and excerpts from the book are imprinted on the exhibition rooms' walls. The purpose of the exhibition, like that of the book, is to exalt Portugal's deeds in the East.

The exhibition is organized in three main sections and occupies the entire first floor of the museum building. There is no prescribed route that the visitor must follow, but the visit inevitably begins in the central section of the exhibition space, where the staircase and access to the first floor is located. This central section is dedicated to Macau and is dominated by the presence of four beautifully decorated Chinese screens. Macau life is depicted in several drawings by George Chinnery (1774-1854), the renowned Orientalist painter who spent much of his life portraying Asian landscapes and life. The importance of Macau to international trade is highlighted through a number of objects manufactured in China and destined for European markets.

From this central section, visitors can either go east or west to the other two sections of the exhibition. To the west is a section on "Heritage, Memory, and Collections." The aim of this section is to document the establishment of the Portuguese Empire in the East, starting with Goa, India, and expanding as far as Japan. This led to the development of a network of trading posts in these territories, linked by state-sponsored vessels - the nau do trato (treaty ships) - which traded between the West and the East. The space is almost entirely devoted to India. Indo-Portuguese art is given considerable prominence as a "miscegenate art" - what in English would now be called hybrid art. Visitors are informed that this was the result of objects produced in Portuguese-dominated Asia for both religious and secular purposes. Several objects incorporating local raw materials are displayed, from altar crosses to furniture. Namban art is similarly highlighted, merging with the section on Japan, which is dominated by a Namban screen depicting the arrival of Portuguese merchant ships in Japan. Myanmar, which in the exhibition is still named Birmania (Burma), is represented by lacquerware that became highly appreciated in the West while China is represented by a collection of European-commissioned porcelain items dating from the sixteenth and seventeenth centuries.

The other section is divided into two: an important ethnographic collection from East Timor and a subsection devoted exclusively to what the museum calls "Oriental" art. The latter is eclectic in content and lacks a coherent narrative apart 
from the fact that these are beautiful objects that were being collected in eighteenth- and nineteenth-century Europe. Here China takes up most of the exhibition space, with several objects ranging from the Neolithic period to the eighteenth century, including terracotta and other antiques, porcelain, and ceramics. A section is dedicated to the scholar's cabinet, and to his interest in Chinese culture, including a panoply of curiosities which evoke the eighteenth- and nineteenth-century cabinets of European aristocracy. A few Japanese and Korean antiques are also displayed in this section.

The section on East Timor is an ethnographic collection consisting of everyday and sacred objects, aimed at documenting "the unity and diversity of the cultures in presence as well as the close ties that those peoples have kept with Portugal" (Museu do Oriente 2008, 29). Among the items are silver bracelets, gold necklaces, working tools, ceremonial knives, and masks, which are displayed as works of art, with their aesthetic qualities fully enhanced. Most of the objects date from the twentieth century, although no information is given regarding the context in which they were collected. Nor is there any information about the "close ties those peoples have kept with Portugal," which are not indicated by the objects themselves.

Overall, historical contextualization is provided for visitors through the written text, in both English and Portuguese, which accompanies each object or set of objects. The text is highly descriptive and, besides providing standard data on origin, date, dimensions, and materials, also presents contextual information in relation to trade and the cultural/religious exchange between Portugal and the East. The interpretive principle on which the exhibition is based is that of a "crosscivilization encounter" (Museu do Oriente 2008, 88) between West and East through mutually beneficial commercial relations. The following text from the exhibition, which introduces Macau to visitors, reflects the emphasis placed on trade, the decorative arts, and the cultural interchange in the interpretive framework:

The Portuguese brought their customs, their language, their beliefs, technical skills and learning to Macau. And they encountered in Macau the roots of Chinese civilization stretching back thousands of years. Throughout centuries of interaction between Portuguese and Chinese representatives, there were constantly phenomena of symbiosis and acculturation.

Porcelain items began to be used for domestic decoration as well as for undertaking different domestic tasks. The same happened with countless varieties of Chinese silk that began to be incorporated into clothing, quilts and liturgical vestments. Craftsmen adopted ceramics, furniture, tapestries and so many other Chinese decorative items and utensils to the specific decorative requirements and tasks of the Western world.

The communication with the visitor is, thus, strongly based on the aesthetic qualities of the objects, which are displayed as art objects, although they are presented with contextual information. Most of them are decorative or art objects, and there 
are few meant for ordinary or everyday use. The objects are exhibited in big showcases, and no use is made of multimedia or technological devices to give visitors additional information, except a very short film about contemporary Goa and the remaining evidence of Portuguese presence there. The exhibition space is poorly illuminated and spotlights are directed at the objects themselves to enhance their aesthetic qualities. The few visitors wander around the showcases without following any defined route. Overall, the objects are presented as "treasures" which progressively reveal themselves as the visit unfolds. This was the deliberate intention of the curators of the museum, as stated in the museum catalogue: "The overall environment felt by the visitor is one of crossing a sinuous "cave of treasures", (Museu do Oriente 2008, 23) and feeling the "surprise caused by the progressive revelation of the artwork or the most significant cultural testimonies, whose contextual reading is done discreetly but effectively" (Museu do Oriente 2008, 25). The interpretive framework thus directs the experience to the field of emotions - the emotion of "discovering" the "treasures" of distant places and times.

\section{Captivating artifices}

The Portuguese Presence in Asia presents us with a collection of objects that unsettle the strict classifications between works of art and artifacts, both being conceived as aesthetic objects. As Nayanika Mookherjee tells us, this is one of the most productive ways to produce affect toward the nation and its past: "These embodied, sensual aesthetic artefacts are not only seen to generate and circulate various affects. It is through these affective experiences that the public and the nation are created" (Mookherjee 2011, S5). The affective power of aesthetic artifacts goes far beyond straightforward forms of representation. Instead, their significance comes from the fact that they are involuntarily perceived by feelings and senses, thus remaining ambiguous and vague, although charged with meaning.

Alfred Gell's view of the special kind of agency some objects have might be useful here. In Art and Agency (1998), Gell pointed out the agency of things and the wide range of implications for the material and sensual practices that go with identity discourses. Objects, as well as people, he tells us, have an agency of their own, that is, they are embedded in a system of social relations within which they are called on to act (Gell 1998, 26). Agency is mediated by indexes, that is, the material objects which motivate responses, inferences, and interpretations. Art objects, according to Gell, are particularly powerful indexes. Their agency comes neither from their aesthetic value nor from the symbolic propositions they encode. Instead, it comes from their performative powers as actors in their own right in the service of action and within a structure of intentions. Therefore, an artwork only exists as long as it is interpreted as such within a historically specific art world - for instance, by being displayed in a museum. Thus, almost anything can be considered to constitute an object of art. 
Gell (1998, 68-69) also argued that the special kind of agency and the "canonical" efficacy that art objects have reside in their power of fascination: "they fascinate, compel, and entrap as well as delight the spectator" (1998, 23). They are technologies of "captivation" or "traps" (Gell 1998; 1996), in the sense that the agency that lies beyond them becomes indecipherable to the viewer, who is unable "to rehearse the origin of the index from the point of view of the originator, the artist" (Gell 1998, 71). Although the product of a series of technical gestures, a work of art is perceived by its "recipients" (those who are affected by them), and even by the artists themselves, as the result of a "miraculous creation" (Gell 1998, 68). This perception is enhanced by both the technical virtuosity and the visual properties of art objects which, according to Gell, "exploit the intrinsic mechanisms of visual cognition with subtle psychological insight” $(1998,68)$.

The museographic options adopted in the The Portuguese Presence in Asia - displaying the objects in glass cases, together with the focus on visuality - illustrate the captivating power of the display. Despite the fact that the objects are frequently - but not always - paired with texts that contextualize them, history is mainly mediated by the objects displayed, and not by the information provided by the texts that accompany them. In other words, historical knowledge is first accessed in the context of the exhibition through the visualization of objects and their aesthetic features. On the one hand, this is because the texts are much denser and require a certain kind of willingness to learn, and, on the other, it is because the objects have a theatrical dimension which facilitates an immediate perception. This is further accentuated by the fact that these are beautiful objects which cannot fail to impress the visitor, and many of them circulated in a market of luxury goods of Eastern provenance. This is a tasteful exhibition reflecting the popular fascination of the late seventeenth and eighteenth centuries with exotic objects, especially those of Chinese or Japanese origin (Adams 1992, 38). It also embodies the expansion of the luxury trade in exotic commodities from the sixteenth century onward. The newly established mercantile groups endowed these objects with symbolism and made them requirements for "rites de passage' or for prestige and display of taste" (Berg 2002, 12). Later on, in the eighteenth century, they became "populuxe goods," as Cissie Fairchilds (1993) described them, as a result of the growth in the consumption of foreign-manufactured imports or, even more, of their cheap copies. Empire, new manufacturing technologies, and mercantile policies combined with the eighteenth century's widespread notion of a "science of taste": a training in the art of refinement and aesthetic sensibility (Berg 2002, 12). As noted by Adam Smith in his Theory of Moral Sentiments (1759), aesthetics became a constraint on consumer demand and the principles of beauty acquired a relevance far beyond limited artistic circles.

The emergence and expansion of hybrid art forms, as they are conceived, such as Indo-Portuguese art, Namban art, and the syncretisms between Chinese manufacture and Western decorative motifs must be read in the context of a growing global mercantile economy. The exhibition fully acknowledges these hybrid arts by displaying a profusion of decorative objects - for civilian, military, or religious 
use - which were also objects of prestige and distinction in aristocratic and, later, bourgeois circles, in both Europe and Asia. The people who owned the objects and the objects themselves both embody a particular kind of agency, one that delivers power to particular historical subjects. Nonetheless, the stress on hybridity contributes to the establishment of a certain kind of equality. It creates an exhibitionary ethos around the "richness and exoticism of the materials, the exceptional nature of the technique and the sumptuousness of the objects" (Museu do Oriente 2008, 48) resulting from the material encounter between the Portuguese and the East. In this reading, there is no hierarchy, as both Portuguese and Eastern cultures contributed equally, even though there is no specification with respect to the particularities of the cultures in question: Who were the Eastern peoples? What was Portuguese culture besides a traveling/trading one? Hybridity thus produces homogeneity.

In some cases, the meaning invoked by the objects largely surpasses the one offered in the texts. One example, in a section on the importance of missionary activity in tandem with the commercial enterprise, is two big sculptures of missionaries who were martyred hanging on a cross. Several texts mention that missionaries faced many perils, but the presence of these two sculptures adds a visceral dimension to the idea that the Portuguese "mission" was both sacred and involved sacrifice. This same sensibility is also noticeable in the East Timor section, although it is not as obvious. East Timor was a residual Portuguese colony when, in 1975, in the wake of Portuguese decolonization, it was occupied by Indonesia. The Portuguese were forced to withdraw, and a nationalist movement against occupation grew, which made use of the emotional and cultural ties with the Portuguese (Portuguese language and Catholicism) as a form of resistance against Indonesian occupation. The violence inflicted by Indonesia on the people of East Timor, in particularly the massacre of 1991, led to an international movement pressing for the independence of East Timor. In Portugal, solidarity with the cause grew stronger and culminated in a major public demonstration in 1999 appealing for the independence of the former colony. This was, as Miguel Vale de Almeida (2002) has noted, the first political demonstration relating to Portugal's colonial past since the fall of the dictatorship in 1974. East Timor is the site where the "national catharsis around issues of colonialization, decolonialization, and ... national identity" (Almeida 2002, 583) took shape the site, I would add, where loss was reintegrated into the national past, not by Portugal assuming the role of the colonial perpetrator, but by it being an "excuser" of history's fallacies. East Timor's fight for independence and Portugal's participation in it are at the heart of Portuguese postcolonial identity, and are not missed in the exhibition. Imprinted on the wall next to the section on East Timor is an excerpt from a 1968 poem by Ruy Cinatti, a Portuguese poet and anthropologist:

Timor re-emerges from waters

Future beach invoked

...

Timor grows with a scream

Echoing within all of us. 
Not only are the nonwritten communicative devices in the exhibition loaded with affective power; the written messages, too, function as affective registers through which the nation's past is emotionally unveiled.

\section{Utopian geographies}

As Benedict Anderson (1983) reminds us, maps are fundamentally artifices for imagining the geobody of a nation. Dipesh Chakrabarty $(2002,7)$ adds that maps play a crucial role in a pedagogic model of democracy, giving citizens the capacity to imagine and visualize the geographical extent of the nation. The same goes for empires and the way they are perceived in colonial centers through "imagined geographies" (Said [1978] 1995). In Portugal, too, hundreds of maps were drawn and distributed to feed the imperial imagination, instilling in its population a perception of the geography of the country as inseparable from its colonial dominion.

Nevertheless, the period known as the Eastern Empire strongly resists mapping and geographic location in the way it is popularly imagined. Although it has been represented through maps, it has been imagined mainly through poetic devices, mostly literature and poetry. Camões's epic poem The Lusiads and his depiction of the Orient as a mythical place have been deeply ingrained in the Portuguese national imagination. The Lusiads is full of geographical descriptions as it follows Vasco da Gama's journey from Portugal to India in 1497-1498. Indeed, Camões owes much to geography, as the book is full of details of the distant places to which da Gama traveled: Timor sends sandalwood, healthful and fragrant (X, 134); in Ceylon a hill rises up in the sky, and in the Maldivian islands there is a powerful antidote against poisoning (X, 136); Madagascar is a famous island (X, 137); and, he concludes, all this is the Orient, which the Portuguese now give to the world by opening the door of the vast ocean (X, 138).

Fernando Pessoa has also offered an impressionistic view of the Orient, defining it not as a geographical but as a spiritual location, "whence all comes, the day and the faith, pompous and bigoted and hot, ... a place where God might actually exist," in the words of his heteronym Álvaro de Campos (in Dois Excertos de Odes). In spite of the Orientalizing process, the Orient existed as a utopian place in the Portuguese national imagination which resisted precise geographical locations and historical classification. As Bernardo Soares (another Pessoa heteronym) wrote in the Book of Disquiet (Livro do Desassossego): "My imagination is a city in the Orient." It cannot be sited, located, controlled, defined, or limited. Nor can it be given any shape, structure, or hierarchy. It is a utopian geography. In this reading it can be understood as a "rhizome," constantly moving across an endless surface, unsitable, and smooth (Deleuze and Guattari 1987). But this must not mislead us into thinking that the imagination of the Orient is a purely horizontal one. It has its genealogy, its verticality, its meaning-laden memory (Navaro-Yashin 2009). It also has its "roots" (it is a trace of a historical event - Portuguese imperial endeavor); it is sited (it refers to specific parts of the East and excludes others); it 
is charged with political meaning (it refers to a perception of space created through certain images, texts, or discourses); and it is remembered through museum practices.

The Portuguese Presence in Asia dwells strongly on the notion of a utopian geography. The exhibition includes three maps: one of southern Asia dated 1654 displayed at the entrance to the section on the Portuguese Eastern Empire, and the other two, dated 1561 and 1601, placed side by side at the end of this section which depict eastern Asia. They are all very small maps. In addition, they were drawn according to the principles of premodern geography and lack systematic measurements. As such, they barely correspond with today's general view of the geography of the globe and are of little use in clarifying the geography of the places in Asia where the Portuguese exerted their influence. Instead, location is given by the textual information alongside the objects as part of a larger historical contextualization. A profusion of names of exotic and far distant places are offered. We are told, for instance, that "from Malacca, the Portuguese advanced to the Moluccas, Siam, Pagu and China," and that after the arrival of rival powers the Portuguese were able to maintain possessions on the coast of East Africa, corresponding to today's "Republic of Mozambique, Diu, the North Province (Daman, Bassein, Bombay and Chaul), Goa and its neighbour provinces (Bardez and Salcete) as well as Timor and Macau." As with the maps, geography becomes blurred because of the inability to geographically imagine the places named. They thus remain captivating nomenclatures, indexes of the process by which an Orientalizing utopian geography is produced. The Orient remains a distant place, inhabited by distant peoples and located in the depths of the Portuguese national imagination. The inscription of a verse of The Lusiads at the entrance of the section on the Portuguese Eastern Empire attests to this: "And among far distant peoples to proclaim a new age and win undying fame" (I, 1). This poetic sense attributed to geography is also present in the section of East Timor, which is introduced with another excerpt from The Lusiads: "There also lies Timor that timber sends purposeful and aromatic sandalwood" (X, 134). A sensorial engagement with place is thus suggested, infusing imagination with exotic fragrances.

That the exhibition space is not partitioned by physical barriers between the different sections, and visitors are able to wander through the space and through different geographical areas, makes it easy to confuse the different locations and hard to place them within a coherent historical and geographical narrative. It is also difficult to establish a historical relation between certain places. One wonders, for instance, what kind of connection can be made between life in the colony of Macau as depicted in George Chinnery's paintings and the ceremonial objects of East Timor. In addition, the objects seem to be disembodied from the geographically based units from where they originated and from the processes and institutional structures through which they were disseminated and used. Historical contextualization is, for the most part, based on a macro level of interpretation 
which produces an all-encompassing and homogenizing scale of representation that rests on a discourse of international trade and cultural exchange. The narrative put forward in the exhibition space is, thus, largely diffusionist, that is, it traces the diffusion of cultural forms emerging from the contact between peoples in the context of the establishment of global commercial relations. Some of the texts in the exhibition give full credit to this: for instance, we are told that the "profitable trading expeditions ... set down the foundations for what is now known as globalization" or that "The globalization process, unleashed by the Portuguese ... was irreversibly spread to the whole continent of Asia."

The exhibition thus builds on common constructs of trade according to which trade is conceived as the traffic in commodities "through peaceful human agency" (Adams 1992, 242). This construct suggests, in the words of Robert Adams, "the essential isolation of the borrowing process from a broad historical and interactional setting" (1992, 240). So the utopian geography of The Portuguese Presence in Asia must be understood as both horizontal - an endless plateau with no specific location - and vertical - the result of specific historical power relations (NavaroYashin 2009).

\section{Elusive temporalities}

The exhibition is structured so as to highlight issues both of ownership over former colonial territories (of spiritual property) and of antiquity (the intemporality of the nation and of its cultural domain). And it does that by establishing a time that is nonlinear: it has no beginning and no end, being just a circular labyrinthic "meanwhile" of adjacent spaces, a device used to structure the narratives of the modern nation as put forward by Benedict Anderson (1983, 24-25). The temporal sequences are seldom more than very roughly defined, and chronology often gets blurred. Also, it is difficult to specify the units of time in which relationships may be traced between peoples and regions. When did exchange occur, where, and between which agents? What was the generative role of change in the long history of the relations presented? It is true that change is sometimes acknowledged, such as when a reference is made to the arrival in 1598 of rival Western powers in the trading routes, or to Macau's loss of importance in the eighteenth century. But, in the whole temporal narrative of the exhibition space, these are nothing more than mere footnotes in the flow of a multiplicity of temporal dimensions. In this respect, the exhibition lacks a change-oriented view, and concentrates instead on static, synchronic systems of trade and exchange with the implication that these idealized "functions" are the most appropriate to explain their origin and continuity (Adams 1992, 242). Through this captivating exercise, a stable story is settled - and separated from the discourse that generated it.

But this story has a history of its own. The Portuguese arrived in India in 1498 and, in the ensuing decades, established a series of fortifications and trading 
posts along the coasts of Africa, the Middle East, India, and eastern Asia, supported by the religious missions on land. In 1571 Lisbon was connected to Nagasaki in Japan via a commercial network that gave the Portuguese control over the trade in spices, gems, silk, and porcelain. In the first half of the sixteenth century Lisbon was Europe's "emporium," but by the end of the century the Portuguese monopoly over Eastern commerce was growing weaker in the face of increasing competition from emerging imperial powers such as Holland, France, and England. During the seventeenth century, Macau was constantly attacked by the Dutch; the Portuguese were expelled from Japan and Christianity was strongly persecuted there; and the control of trade with China was lost. The economy of Macau was seriously affected, although it was able to maintain its economic and strategic importance as a European commercial port in China. However, the foundation of Hong Kong in 1841 by the British eventually led to a dramatic decline in the commercial activity of Macau. Unable to compete with Hong Kong, the government of Macau decided to gain revenue by granting licenses for specific activities. In the nineteenth century the most important monopolies held by Macau were gambling and the opium trade and, when opium was banned in 1947, gold and then tourism, as well as gambling, became the most important activities in the colony.

After 1974, Portugal and China agreed a peaceful transfer of Macau to Chinese sovereignty, which was to take place on December 20, 1999. The transfer of Hong Kong had already taken place on July 1, 1997. Portugal turned out to be the first European nation to arrive in China and the last one to leave. It is this sense of permanence that is explored in The Portuguese Presence in Asia. Being the first and the last establishes an elusive temporality that explores continuity rather than change or rupture: the continuity of good diplomatic and commercial relations between Portugal and China extending beyond colonial times, until today, and hopefully into the future. The presence of objects that bear out the good relations between Portugal and China (and other Eastern countries) in the space of one of Portugal's newest museums are a testament to that continuity. As Henri Bergson noted, matter does not remember the past; it repeats it constantly (Bergson [1896] 1991, 223).

It is this sense of continuity and repetition that the museum curators envisage when they state that the museum intends to "provide the Portuguese and those who visit us a living and actuating memory of Asian cultures and of the secular relationship that was established between the East and the West, primarily through Portugal" (Museu do Oriente 2008, 22). The academic disciplines that are called on to participate in that memory are history, art history, and anthropology, which are performed as nostalgic disciplines seeking to give continuity to the past in spite of the ravages of time. One cannot help noticing everywhere in the exhibition space a palpable sense of nostalgia and loss, a sense that is refined by an equally powerful sense of transcendence, of utopia. Presented in showcases, as "treasures" of the Portuguese past, the objects themselves discharge powerful nostalgic feelings. The 
exhibition space, therefore, presents visitors with an environment of ruins in which, in the context of particular historical contingencies - both colonial and postcolonial - objects come to mediate historical experience, affecting ingrained shared feelings about it. As such, the Museu do Oriente is a temple, in which a time long gone and another time yet to come are performed through the actual presence of its material registers.

\section{Notes}

1 http://whc.unesco.org/en/list/263 (accessed October 20, 2014).

2 http://www.foriente.pt/62/macau.htm\#.VFGD196ai-Y (accessed October 30, 2014).

\section{References}

Adams, R. M. 1992. "Anthropological Perspectives on Ancient Trade.” Current Anthropology 33(1): 141-160.

Almeida, M. V. de. 2002. "Epilogue of Empire: East-Timor and the Portuguese Postcolonial Catharsis." Identities 8(4): 583-606.

Anderson, B. 1983. Imagined Communities: Reflections on the Origins and Spread of Nationalism. London: Verso.

Berg, M. 2002. "From Imitation to Invention: Creating Commodities in EighteenthCentury Britain.” Economic History Review 55(1): 1-30.

Bergson, H. (1896) 1991. Matter and Memory. New York: Zone.

Bethencourt, F., and K. Chaudhuri, eds. 1999. História da Expansão Portuguesa [History of Portuguese Expansion], vol. 5. Lisbon: Círculo de Leitores.

Chakrabarty, D. 2002. "Museums in Late Democracies." Humanities Research 9(1): 5-12.

Deleuze, G., and F. Guattari. 1987. A Thousand Plateaus: Capitalism and Schizophrenia. Minneapolis: University of Minnesota Press.

Dudley, S. H. 2010. "Museum Materialities: Objects, Sense and Feelings.” In Museum Materialities, edited by S. H. Dudley, pp. 1-17. London: Routledge.

Fairchilds, C. 1993. "The Production and Marketing of Populuxe Goods in EighteenthCentury Paris." In Consumption and the World of Goods, edited by J. Brewer and R. Porter, pp. 228-248. London: Routledge.

Gell, A. 1996. "Vogel's Net: Traps as Artwork and Artworks as Traps.” Journal of Material Culture 1(1): 15-38.

Gell, A. 1998. Art and Agency: An Anthropological Theory. Oxford: Oxford University Press.

Gregory, K., and A. Witcomb. 2007. "Beyond Nostalgia: The Role of Affect in Generating Historical Understanding at Heritage Sites.” In Museum Revolutions: How Museums Change and Are Changed, edited by S. Knell, S. MacLeod, and S. Watson, pp. 263-275. London: Routledge.

Henare, A., M. Holbraad, and S. Wastell, eds. 2007. Thinking through Things: Theorizing Artifacts Ethnographically. London: Routledge. 
Latour, B. 2005. "From Realpolitik to Dingpolitik or How to Make Things Public.” In Making Things Atmospheres in Democracy, edited by B. Latour and P. Weibel, pp. 14-43. Cambridge, MA: MIT Press.

Law, K. 2013. "The Red Line European Colonialism: Comparison of the Macao Museum and Hong Kong Museum of History after Their Return to China.” International Journal of Heritage Studies 20(5): 534-555.

Massumi, B. 1987. "Notes on the Translation and Acknowledgements." In G. Deleuze and

F. Guattari, A Thousand Plateaus, pp. xvi-xix. Minneapolis: University of Minnesota Press.

Mookherjee, N. 2011. "The Aesthetics of Nations: Anthropological and Historical Perspectives." Journal of the Royal Anthropological Institute 17: S1-S20.

Museu do Oriente. 2008. Museu do Oriente: Lisboa. Lisbon: Museu do Oriente.

Navaro-Yashin, Y. 2009. "Affective Spaces, Melancholic Objects: Ruination and the Production of Anthropological Knowledge." Journal of the Royal Anthropological Institute 15: 1-18.

Peralta, E. 2011. "Fictions of a Creole nation: (Re)Presenting Portugal's Imperial Past.” In Negotiating Identities: Constructed Selves and Others, edited by H. V. Bonavita, pp. 193-217. Amsterdam: Rodopi.

Power, M., and J. D. Sidaway. 2005. “Deconstructing Twinned Towers: Lisbon's Expo ’98 and the Occluded Geographies of Discovery." Social \& Cultural Geography 6(6): 865-883.

Prado Coelho, J. 1983. Camões e Pessoa: poetas da utopia [Camões and Pessoa: Poets of Utopia]. Lisbon: Europa-América.

Presidência da República Portuguesa. n.d. "Discurso do Presidente da República na Cerimónia de Inauguração do Museu do Oriente" [Presidential address at the inauguration of the Museum of the Orient]. Accessed October 30, 2014. http://www. presidencia.pt $/$ idc $=228$ idi $=15875$.

Said, E. (1978) 1995. Orientalism. London: Penguin.

Thrift, N. 2004. "Intensities of Feeling: Toward a Spatial Politics of Affect." Geografiska Annaler 86B(1): 57-78.

Witcomb, A. 2010. "Remembering the Dead by Affecting the Living: The Case of a Miniature Model of Treblinka." In Museum Materialities, edited by S. H. Dudley, pp. 39-52. London: Routledge.

Elsa Peralta is a postdoctoral research fellow at the Institute of Social Sciences (ICS), University of Lisbon, Portugal. Her work focuses on questions of local and national identities, museums, heritage, and memory. She explores the intersection between private and public modes of recall of past events and is currently working on the memory and forgetting of the Portuguese colonial empire in postcolonial Portugal. Her works include the edited volumes Heritage and Identity: Engagement and Demission in Contemporary Society (with Marta Anico; Routledge, 2009) and Cidade e Império: dinâmicas coloniais e reconfigurações pós-coloniais (City and empire: Colonial and postcolonial dynamic configurations; with Nuno Domingos; Edições 70, 2013). 